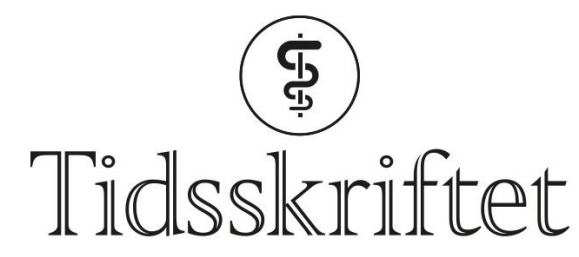

DEN NORSKE LEGEFORENING

\title{
Ingen effekt av kirurgi ved skuldersmerter
}

FRA ANDRE TIDSSKRIFTER

ØYVIND STOPLE SIVERTSEN

Tidsskriftet

Ved subakromialt smertesyndrom i skulder er konservativ behandling like effektivt som artroskopisk dekompresjon eller narrekirurgi.

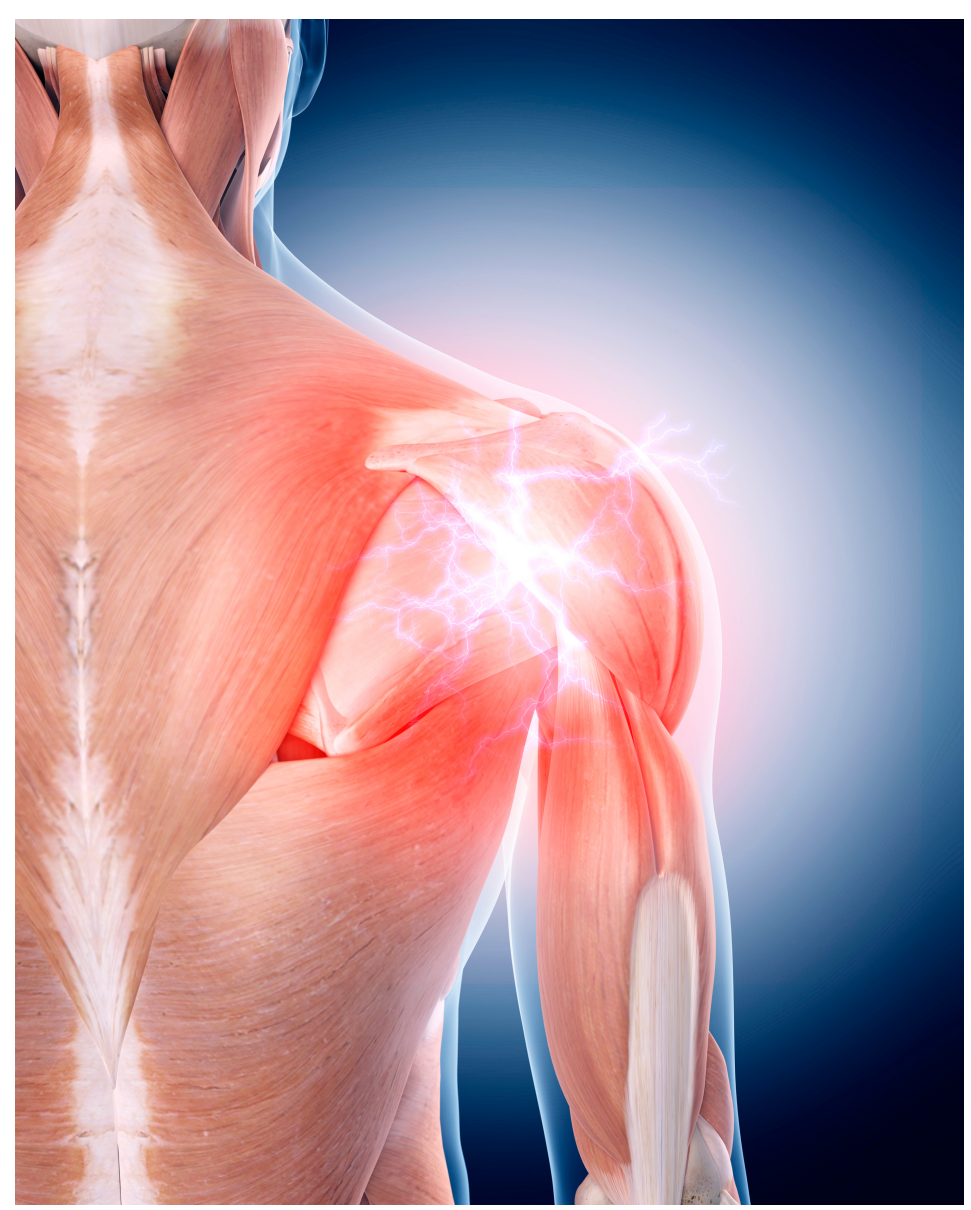

Illustrasjonsfoto: Science Photo Library/NTB scanpix

Subakromialt smertesyndrom i skulder behandles ofte med artroskopisk subakromial dekompresjon, det vil si at ben og/eller bløtvev under akromion fjernes for å skape bedre plassforhold. Effekten er imidlertid dårlig vitenskapelig dokumentert.

I en studie som nylig er publisert i The Lancet (1), ble 313 pasienter med subakromiale 
smerter i minst tre måneder, intakte sener i rotatormansjetten og tidligere behandling med fysikalsk trening og minst én steroidinjeksjon, randomisert i tre grupper. Pasientene fikk enten artroskopisk subakromial dekompresjon, artroskopi uten kirurgi (narrekirurgi) eller ingen kirurgisk behandling. Pasientene i sistnevnte gruppe fikk en oppfølgingsvurdering av en skulderspesialist tre måneder etter inklusjon.

Etter seks måneder hadde alle tre gruppene bedre skulderfunksjon. Det var ingen forskjell i skuldersmerter mellom gruppen som fikk artroskopi med eller uten subakromial dekompresjon. I disse gruppene rapporterte pasientene litt mindre skuldersmerter enn i gruppen som ikke fikk kirurgisk behandling, men forskjellen angis ikke som klinisk viktig. Det var for $ø$ vrig to tilfeller av skulderkapsulitt i hver av de tre gruppene.

- Denne studien forsterker mistanken om at diagnosen subakromialt smertesyndrom, ofte kalt impingement, blir stilt for ofte. Så tilbys de operasjon, sier Frode Hellum, overlege ved Ortopedisk avdeling ved Akershus universitetssykehus.

- Diagnosen er dårlig definert, og klinisk erfaring tyder på at mange pasienter med subakromialt smertesyndrom har smerter fra andre strukturer i skulderen. Denne studien bekrefter i så måte at en isolert subakromial dekompresjon ikke gir noen gevinst eller bedret skulderfunksjon, sammenlignet med ingen behandling, understreker han.

- Ved norske sykehus har det de senere årene vært en holdningsendring i retning av mer konservativ behandling ved subakromialt smertesyndrom. Studien tyder på at denne endringen har vært riktig. Samtidig tror jeg noen pasienter med åpenbare påleiringer og/eller forkalkninger av korakoakromialligamentet og mekaniske symptomer vil kunne ha nytte av kirurgi, sier Hellum.

\section{LITTERATUR:}

1. Beard DJ, Rees JL, Cook JA et al. Arthroscopic subacromial decompression for subacromial shoulder pain (CSAW): a multicentre, pragmatic, parallel group, placebo-controlled, three-group, randomised surgical trial. Lancet 2018;391:329-38. [PubMed][CrossRef]

Publisert: 8. mai 2018. Tidsskr Nor Legeforen. DOI:10.4045/tidsskr.18.0197

(C) Tidsskrift for Den norske legeforening 2020. Lastet ned fra tidsskriftet.no 